\title{
Marka Aşkının Marka Deneyimi ile Marka Sadakati Arasındaki ílişkiye Aracılık Etkisi ${ }^{1}$
}

\author{
The Mediating Role of Brand Love on the Relationship between Brand Experience and \\ Brand Loyalty
}

Nilay AŞKIN', illayda IPEK²

\begin{abstract}
ÖZET
Çalışmanın amacı marka aşkının marka deneyimi ile markasadakatiarasındakiilişkiüzerindearacılıketkisi olup olmadığını incelemektir. Kavramsal çerçeve ve hipotezler otomobil markaları ile deneyim yaşamış olan 178 katılımcının oluşturduğu bir örneklem ile analiz edilmiştir. Elde edilen veriler yapısal eşitlik modeli kullanılarak test edilmiştir. Çalışmanın bulguları, marka aşkının marka deneyimi ile marka sadakati arasındaki ilişki üzerinde tam aracılık etkisi yarattığını göstermektedir. Bu çalışma yöneticilere önemli öneriler sunmaktadır. Yöneticilerin hedef tüketiciler üzerinde marka deneyimi yaratacak ve dolayısı ile marka aşkını güçlendirecek stratejilere daha fazla önem vermeleri halinde tüketicilerin marka sadakatlerinin artması beklenmektedir.
\end{abstract}

Anahtar Kelimeler: Marka deneyimi, marka aşkı, marka sadakati

\begin{abstract}
This study attempts to propose and test a conceptual model that investigates the mediating role of brand love on the relationship between brand experience and brand loyalty. The conceptual model and relevant hypotheses are analyzed with a sample of 178 consumers who have experienced with automobile brands. Data were tested through structural equation modeling. The results demonstrate a full mediation role of brand love on the linkage between brand experience and brand loyalty. This study offers such interesting implications that as managers attach more importance to the strategies creating brand experience on target customers, which in turn, enhances the brand love, customers are expected to be more loyal to brands.
\end{abstract}

Keywords: Brand experience, brand love, brand loyalty

\section{GíRiş}

Deneyimsel pazarlama ortaya çıktığından beri rekabet üstünlüğü yaratmak için şirketler tarafından stratejik bir silah olarak kullanılmaktadır. Deneyimsel pazarlama kavramı ilk defa "tüketimin deneyimsel boyutları" ortaya konularak ele alınmıştır (Holbrook ve Hirschman, 1982). Pazarda rekabet üstünlüğü yaratmak için firmaların müşterilere sundukları ürün veya hizmetleri güçlendirmeleri gerektiği vurgulanmış, bunun için müşterilere benzersiz deneyimler sunmanın etkili bir yol olduğunun altı çizilmiştir (Pine ve Gilmore, 1998: 98). Daha sonra, marka deneyimi kavramı literatüre kazandırılarak, bu yeni alan güçlendirilmiştir (Schmitt, 1999). Marka deneyiminin müşteri memnuniyeti yaratma ve sonrasında müşteri sadakatine dönüştürmede önemli bir rol oynadığı yapılan akademik çalışmalarla kanıtlanmıştır (Brakus vd., 2009;
Chang ve Chieng, 2006; Nadiri ve Günay, 2013; Zarantonello ve Schmitt, 2010).

Bunun yanı sıra, araştırmacılar yıllardan beri tüketicilerin markalara karşı sevme/sevmeme duyguları üzerine çalışmalarına rağmen, son birkaç yılda hem akademisyenlerin hem de uygulamacıların "tüketicilerin markalara olan aşkı" konusuna gösterdikleri ilgide hızlı bir artış görülmektedir. Literatürde son yıllarda marka aşkı ve bununla bağlantılı diğer kavramlar üzerine yapılan çalışmalar yoğunlaşmış olup, marka aşkının; özellikle marka sadakati, ağızdan ağıza pazarlama gibi marka yönetimi açısından önem arz eden yapılar ile ilişkileri araştırılmaktadır (Albert vd., 2008; Batra, vd., 2012; Carroll ve Ahuvia, 2006). Uygulama tarafında ise, Roberts (2004) aşk markaları fikrini geliştirmiştir. Ayrıca, aşk kavramının marka reklamlarında da sık sık vurgulandığı görülmektedir (Bauer vd., 2009: 252). 
Yapılan akademik çalışmalarda marka aşkının temelinin tüketicilerin markalarla yaşamış oldukları deneyimlere dayandığı görülmektedir (Batra vd., 2012; Fournier, 1998). Bu bulgular ışığında, marka aşkının marka deneyimi ve marka sadakati arasındaki ilişkiye aracılık edebileceği ve bu aracılık etkisi ile marka deneyiminin marka sadakati üzerinde daha güçlü bir etki yaratacağı beklenmektedir. Çünkü tüketicilerin marka ile yaşamış oldukları deneyimlerin, o markalara karşı hissettikleri olumlu duyguları güçlendirerek, marka sadakatlerini daha da arttırması muhtemeldir.

Çalışmanın amacı, marka aşkının marka deneyimi ve marka sadakati arasındaki ilişki üzerindeki aracılık etkisini incelemektir. Çalışmada yanıt aranan araştırma soruları ise şunlardır: (1) Marka deneyiminin marka aşkı üzerindeki etkisi nedir?; (2) Marka aşkının marka sadakati üzerindeki etkisi nedir?; (3) Marka deneyiminin marka sadakati üzerindeki etkisi nedir?; ve(4) Marka aşkının marka deneyimi ile marka sadakati arasındaki ilişki üzerinde aracılık etkisi var mıdır?.

Çalışma, altı bölümden oluşmaktadır. Illk bölümde giriş, ikinci bölümde ise konuya ilişkin literatür ele alınmıştır. Üçüncü bölümde, kavramsal model oluşturulması ve hipotezlerin geliştirilmesinden bahsedilmiştir. Dördüncü bölümde çalışmanın metodolojisi yer almaktadır. Beşinci bölümde ise, analiz ve bulgular tartışılmıştır. Son olarak altıncı bölümde, sonuç ve öneriler sunulmuştur.

\section{KONUYA ILIŞKIN LITERATÜR}

\subsection{Marka Deneyimi}

Marka deneyimi Schmitt'in (1999) deneyimsel pazarlama literatürüne kazandırdığı önemli kavramlardan biridir (Schmitt ve Zarantonello, 2013: 35). Marka deneyimi Brakus vd. (2009: 53) tarafından "öznel, içsel tüketici tepkileri (duyular, duygular ve kavrama) ile markanın tasarımı, kimliği, ambalajı, iletişimi ve çevresine ait marka uyarıcılarıyla çağrışım yapan tüketicilerin davranışsal tepkileri" olarak tanımlanmıştır.

Schmitt (1999: 60) marka deneyimi için beş farklı stratejik deneyimsel modül belirlemiştir: Duyusal deneyimler, (örn. Volkswagen New Beetle'ın özgün tasarımı), duygusal deneyimler (örn. Volkswagen New Beetle'ın duygusal yakınlık, nostalji gibi hisler uyandırması), düşünsel deneyimler (örn. Volkswagen
New Beetle tasarımının geçmiş ve geleceğe ait öğeleri aynı anda içermesi), davranışsal deneyimler (örn. Volkswagen New Beetle satın alan tüketicilerin bireyselci davranışlarını yansıtabilmesi) ve ilişki deneyimleri (örn. ortak deneyimlere sahip olan Volkswagen New Beetle sahiplerinin aynı topluluğun üyeleri olmaları). Schmitt'e göre (1999: 60), şirketlerin bu modüller aracılığı ile tüketicilere farklı deneyimler sunabilmeleri mümkündür.

Marka deneyimi üzerine yapılan çalışmaların çoğu marka deneyimi, müşteri sadakati, ve müşteri memnuniyeti arasındaki ilişkiyi marka deneyiminin stratejik modülleri aracılığı ile analiz ettiğinden bu modüllere deneyimsel pazarlama alanında büyük bir önem verilmektedir (Brakus vd., 2009; Chang ve Chieng, 2006; Nadiri ve Günay, 2013; Zarantonello ve Schmitt, 2010).

\subsection{Marka Aşkı}

Marka aşkı tüketici davranışları alanında son zamanlarda ortaya çıkan ve hızla gelişmekte olan bir kavram olarak yer almaktadır (Roy vd., 2013: 326). Bazı araştırmacılara göre, "marka aşkı" kavramı aslında psikolojide yer alan "kişilerarası aşk" kavramından gelmektedir (Carroll ve Ahuvia, 2006: 81, Shimp ve Madden, 1988: 163; Thomson vd., 2005: 77). Bu doğrultuda, Sternberg (1986: 3) tarafından oluşturulan "Üçgen Aşk Kuramı" tüketici-marka ilişkisi üzerine adapte edilmiştir (Shimp ve Madden, 1988: 163). Bundan başka, tüketicilerin markalara karşı güçlü hisler besleyebilecekleri söylenmiştir (Fournier, 1998: 360). Bu alanda yapılmış olan önceki çalışmalara dayanarak, tatmin olmuş müşterilerin o markaya karşı hissettikleri aşk, literatüre yeni bir kavram kazandırılarak "marka aşkı" olarak adlandırıımıştır (Carroll ve Ahuvia, 2006: 80). Bu çalışmadan itibaren marka aşkı kavramı marka yöneticileri ve pazarlama araştırmacıları tarafından önem verilen konulardan biri haline gelmiştir.

Diğer bir yandan, marka aşkı kavramının kişilerarası aşk kavramından farklı olabileceği ve bu nedenle de kişilerarası aşk üzerine kurulmuş olan teorilerin doğrudan marka aşkı ile ilişkilendirilmesinin doğru olmadığı öne sürülmüştür (Batra vd., 2012: 1). Ayrıca, birçok duygunun etkileşim içerisinde olduğu karmaşık bir yapı olan marka aşkı kavramını tek boyutlu bir ölçek yerine çok boyutlu bir ölçeğin daha iyi açıklayabileceği savunulmuştur (Albert ve Merunka, 2013: 259). 


\subsection{Marka Sadakati}

Marka sadakati, Dick ve Basu (1994: 99) tarafından bir bireyin göreceli tavrı ile devamlı müşteri olma arasındaki ilişkinin gücü olarak tanımlanmıştır. Deneyimsel pazarlamada, şirketlerin en büyük amaçlarından biri tüketicilere özel deneyimler sunarak, sürecin sonunda marka sadakati yaratmaktır.

Oliver'a (1999: 35-36) göre, marka sadakati bilişsel sadakat, duygusal sadakat, çabasal sadakat ve eylemsel sadakat boyutlarından oluşmaktadır. Bilişsel sadakate göre, tüketiciler marka hakkında edindikleri bilgilere ya da marka ile ilgili olarak yaşamış oldukları deneyimlere bağlı olarak bir marka için tercihte bulunurlar. Duygusal sadakat tüketicilerin markayı beğenmeleri ve o markadan memnun kalmaları sonucunda ortaya çıkar. Çabasal sadakat ise davranışsal bir sonuçtur. Çabasal sadakatin olduğu durumda, tüketicinin markayı tekrar satın alma niyeti ve isteği oluşmaktadır. Son olarak, eylemsel sadakatte tüketicinin satın alma niyetinin ve isteğinin satın alma davranışına dönüştüğü görülür. Bu çalışmada marka sadakati bilişsel, duygusal ve çabasal olmak üzere üç boyutta incelenecektir.

\section{KAVRAMSAL MODEL VE HIPOTEZLERIN GELIŞTíRILMESi}

Marka aşkının marka deneyimi ve marka sadakati arasındaki aracılık etkisini incelemeye yönelik oluşturulan kavramsal model Şekil 1'de gösterilmektedir. Buna göre, marka deneyimi marka aşkının, marka aşkı ise marka sadakatinin bir öncülüdür. Marka deneyimi marka sadakatini doğrudan etkilemektedir ve aynı zamanda marka aşkı üzerinden dolaylı olarak etkilemektedir.

Şekil 1: Kavramsal Model

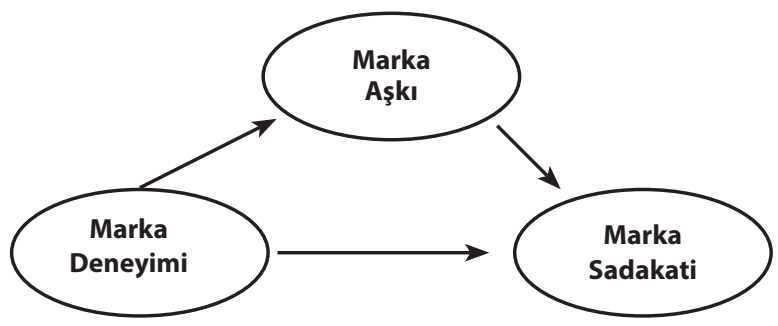

\subsection{Marka Deneyimi - Marka Aşkı Arasındaki ìlişki}

Literatüre bakıldığında, Kumar (1996: 3) tüketim deneyiminden doğan yüksek derecede keyif, mutluluk ve şaşkınlık hislerinden oluşan tüketici hazzının marka aşkının öncüllerinden biri olduğunu belirtmiştir. Haz, tüketim deneyimine karşı oluşan pozitif bir duygu olarak belirtilmiş olup, hazzın müşterinin yaşadığı tüketim deneyiminin uyarılma düzeyine göre düşükten yükseğe; diğer bir deyişle, müşteri memnuniyetinden müşteri hazzına çıkabileceği söylenmiştir (Almeida ve Nique, 2005: 36). Marka deneyimini oluşturan bileşenlerden biri olan duygusal uyarılmanın zaman içerisinde müşteri hazzına (Mano ve Oliver, 1993: 454) ve sonuç olarak da marka aşkına (Roy vd., 2013: 328) dönüşebileceği ifade edilmiştir. Buna ek olarak, tıpkı arkadaşlık ilişkisi gibi senelerce sürebilen aşk ilişkisinin de çok sayıda duygusal, bilişsel ve davranışsal deneyimler içerdiğinin altı çizilmiştir (Fournier, 1998: 363). Marka aşkını oluşturduğu düşünülen değişkenler nitel çalışmalar esnasında, katıımcıların marka hakkında bildirmiş olduğu deneyimlere dayanarak belirlenmiştir (Batra vd., 2012: 3). Bunun dışında, tüketicilere yaşatılan farklı deneyimlerin duygusal sonuçlar yaratan marka aşkı ilişkisi oluşturulmasında etkili olduğu vurgulanmıştır (Langner vd., 2014: 2). Ayrıca, Roy vd. (2013: 328) çalışmalarında, marka deneyiminin marka aşkının öncüllerinden biri olabileceğini önemle belirtmiştir. Bu kapsamda çalışmanın ilk hipotezi şu şekildedir:

$\mathbf{H}_{\mathbf{1}}$ : Marka deneyiminin marka aşkı üzerinde olumlu bir etkisi vardır.

\subsection{Marka Aşkı ve Marka Sadakati Arasındaki ilişki}

Literatürde marka aşkının marka sadakati üzerindeki etkisinin incelendiği birçok çalışmaya rastlanılmaktadır (Batra vd., 2012; Carroll ve Ahuvia, 2006; Fournier, 1998; Thomson vd., 2005). Kişinin o markaya karşı duygusal bir bağ hissetmesinin müşterilerin satın alma davranışından sonraki süreçler üzerinde olumlu bir etki yaratacağı düşünülmektedir. Bunun özellikle marka sadakati üzerindeki etkisini arttıracağı ve bu kişilerin o markaya karşı sadakatlerinin diğer müşterilere göre daha yüksek düzeyde olması beklenmektedir (Roy vd., 2013: 329). Buna ek olarak, farklı deneyimler içeren marka aşkı, öncelikle güçlü duygusal sonuçlara ve bunun sonucunda da marka sadakati gibi davranışsal sonuçlara yol açmaktadır (Langner vd., 2014). Bu nedenle, marka aşkı ile marka sadakati arasında güçlü bir ilişki olduğundan bahsetmek mümkündür (Bagozzi vd., 2014). Ayrıca, literatürde marka aşkının marka sadakatinin öncüllerinden biri 
olduğu belirtilmektedir (Bergkvist ve Bech-Larsen, 2010; Roy vd., 2013). Bunun yanı sıra, birçok ampirik çalışmada da marka aşkı ile marka sadakati arasında istatistiksel olarak pozitif yönlü bir ilişki olduğu görülmektedir (Langner vd., 2014; Bergkvist ve BechLarsen, 2010; Batra vd., 2012; Carroll ve Ahuvia, 2006; Ünal ve Aydın, 2013). Bu kapsamda çalışmanın ikinci hipotezi şu şekildedir:

$\mathbf{H}_{\mathbf{2}}$ : Marka aşkının marka sadakati üzerinde olumlu bir etkisi vardır.

\subsection{Marka Deneyimi ve Marka Sadakati Arasındaki ílişki}

Literatürde marka deneyiminin marka sadakati üzerinde olumlu bir etki yarattığı yapılan farklı çalışmalarla ortaya konulmuştur (Brakus vd., 2009; Chang ve Chieng, 2006; Rameseshan ve Stein, 2014). Marka deneyimi uygulamalarının markalar ve tüketiciler arasında uzun dönemli ilişkiler kurmaya fırsat sağladığı vurgulanmıştır (Chang ve Chieng, 2006). Marka deneyiminin hem tutumsal marka sadakatini hem de davranışsal marka sadakatini olumlu yönde etkilediği desteklenmiştir (Rameseshan ve Stein, 2014). Buna ek olarak, marka deneyiminin alt boyutlarını ayrı ayrı ele alan çalışmalar incelendiğinde, tüketicilere yaşatılan ilişkisel ve duygusal deneyimlerin marka sadakati yaratmada etkili olduğu görülmektedir (Nysveen vd., 2013; Nysveen ve Pedersen, 2014). Bunun dışında, marka deneyiminin marka sadakati üzerinde sadece doğrudan değil aynı zamanda dolaylı etkiye de sahip olduğu ortaya konulmuştur (Ding ve Tseng, 2015; Francisco-Maffezzolli vd., 2014). Buna göre, marka deneyimi marka sadakatini hazcı duygular üzerinden dolaylı olarak etkilemektedir (Ding ve Tseng, 2015). Ayrıca, marka deneyiminin marka ilişki kalitesi aracılığı ile marka sadakati üzerinde dolaylı etki yarattığı ortaya konulmuştur (Francisco-Maffezzolli vd., 2014). Buna dayalı olarak çalışmanın üçüncü hipotezi şu şekildedir:

$\mathbf{H}_{3}$ : Marka deneyiminin marka sadakati üzerinde olumlu bir etkisi vardır.

\subsection{Marka Aşkının Marka Deneyimi ve Marka Sadakati Arasındaki İlişki Üzerine Aracılık Etkisi}

Marka deneyiminin hem dolaylı hem de doğrudan yollarla müşteri sadakatini olumlu olarak etkilediği literatürdeki çalışmalarla ortaya koyulmuştur (Brakus vd., 2009; Iglesias vd., 2011). Bunun yanı sıra, aşk ilişkisi çok sayıda duygusal, bilişsel ve davranışsal deneyimler içermektedir (Fournier, 1998: 363). Ayrıca, marka aşkı kavramı tüketicilerin marka hakkında bildirmiş olduğu deneyimlere dayanarak oluşturulmaktadır (Batra vd., 2012: 3). Literatürde, hem marka deneyiminin hem de marka aşkının, marka sadakati üzerinde olumlu bir etki yarattığına dair çalışmalara rastlanılmaktadır (Brakus vd., 2009; Walter vd., 2013; Batra vd., 2012; Carroll ve Ahuvia, 2006). Buna ek olarak, marka deneyimi ile marka sadakati arasında marka aşkı üzerinden dolaylı bir ilişki olabileceği düşünülmektedir (Roy vd., 2013). Bu nedenle, marka aşkının, marka deneyimi ve marka sadakati arasındaki ilişkiye aracılık ettiğini söylemek mümkündür. Bu durumda, marka aşkı kavramsal modele eklendiğinde $\mathrm{Bu}$ kapsamda çalışmanın dördüncü hipotezi şu şekildedir:

$\mathbf{H}_{4}$ : Marka aşkı, marka deneyimi ve marka sadakati arasındaki ilişkiyi dolaylı olarak azaltmaktadır.

\section{METODOLOJi}

\subsection{Anket Tasarımı}

Çalışmada veri toplama yöntemi olarak beş bölümden oluşan bir anket kullanılmıştır. İlk olarak, katılımcılara markalarla yaşadıkları deneyimleri göz önüne alarak, eğer kendilerine bir otomobil alabilmeleri için seçim hakkı sunulmuş olsaydı, almayı en çok isteyecekleri marka sorulmuştur ve ankette yer alan soruları belirtmiş oldukları markayı düşünerek cevaplamaları istenmiştir. Kişiler araba kategorisindeki markalara karşı daha fazla duygusal bağa sahip oldukları ve kendileriyle ilişkilendirdikleri için, otomotiv sektörünün aşk markalarının oluşmasına daha meyilli bir sektör olduğu düşünülmektedir (Pawle ve Cooper, 2006: 45).

Anket soruları ilgili literatürden yararlanılarak oluşturulmuştur (Ek 1). Marka deneyimini ölçmek amacı ile Brakus vd. (2009) tarafından geliştirilen marka deneyimi ölçeği ve marka aşkını ölçmek için Bagozzi vd. (2014) tarafından geliştirilen marka aşkı ölçeği kullanılmıştır. Marka sadakati ölçeği ise Back ve Parks (2003), Cooper-Martin (1993), Jacoby ve Kyner (1973) ve Mano ve Oliver (1993) çalışmalarından adapte edilmiştir. Anket formunda yer alan sorular 7'li Likert ölçeğine göre hazırlanmıştır (" $1=$ Kesinlikle Katılmıyorum", "7=Kesinlikle Katılıyorum"). Soru formu üzerinde son düzenlemeleri yapmak amacı ile 10 akademisyen üzerinde bir pilot test uygulanmıştır. 
Pilot test sonucunda alınan geri dönüşlere dayanarak anket sorularında anlaşılmayan ifadeler düzeltilmiştir.

\section{2. Örneklem ve Veri Toplama}

Araştırmanın otomotiv sektöründe yapılmasına karar verildikten sonra, İzmir ilinde yaşayan, 18 yaş üzeri ve bir otomobil ile marka deneyimi yaşamış olan (örn., geçmişte markayı kullanan veya marka ile etkileşim kuran -ürünle karşılaşması, televizyon reklamı, broşür, gazete reklamı, web sayfası gibi herhangi bir iletişim aracında görmesi- sonucu edindiği tecrübeler bütünü) kişiler hedef kitle olarak saptanmıştır. Araştırmanın zaman ve bütçe kısıtlarına bağlı olarak, kolayda örnekleme, araştırmanın örnekleme yöntemi olarak belirlenmiştir. Araştırma verileri 2014 yılının Şubat ayında, web ortamında toplanmıştır. Toplam 195 anket toplanmıştır; bunlardan 178 tanesi eksiksiz olarak doldurulduğu için analize dahil edilmiştir. Kullanılabilir anket oranı $\% 91,2$ 'dir.

Araştırma örnekleminin demografik dağılımına bakıldığında, kadınlar ve erkeklerin homojen bir şekilde dağıldığını, örneklemin $\% 50$ lik bölümünü kadınların ve kalan \%50'lik kısmını ise erkeklerin oluşturduğu görülmektedir. Katılımcıların önemli bir bölümünün lisans öğrenim düzeyine sahip olduğu söylenebilir. Araştırma örnekleminin \%51,1'lik bölümünü $18-25$ ve \%23'lük bölümünü ise $26-35$ yaş aralığındaki tüketiciler oluşturmaktadır. Katılımcıların $\% 41^{\prime}$ lik bölümü öğrencileri, \%27,5'luk bölümü ise özel sektör çalışanlarını içermektedir. Katılımcıların gelir düzeylerine bakıldığında, $\% 20,7$ 'lik bölümünün 2001-3000 TL aralığında, \%16,8'lik bölümünün 10012000 TL aralığında ve \%14,6'ık bölümünün ise 30014000 TL aralığında olduğu görülmektedir.

Ayrıca katılımcıların deneyim yaşamış olduğu ve almayı en çok isteyeceği otomobil markalarını belirlemeye yönelik sorulmuş olan soruya verilen yanıtların frekanslarına bakıldığında, BMW (40), Audi (29), Mercedes (21), Volkswagen (15), Mini Cooper (7), Volvo (7), Opel (7), Ford (6), Renault (4) ve diğer (42) en çok belirtilen otomobil markalarını oluşturmaktadır.

\section{ANALIZ VE BULGULAR}

\subsection{Araştırmada Kullanılan Ölçeklerin Güvenilirlik ve Geçerlilik Test Sonuçları}

Çalışmada kullanılan ölçekleri test etmek amacıyla Doğrulayıcı Faktör Analizi (DFA) yapılmıştır. Marka deneyimi, marka aşkı ve marka sadakati ölçekleri için birinci düzey DFA uygulanmıştır (Ek 2). Araştırma kapsamında kullanılan ölçeklerin güvenilirlik ve geçerlilik test sonuçları Tablo 1'de sunulmuştur. Blssad1-Blssad2, Benlik1-Benlik2 ve Blssad4-Blssad5 maddelerinin ifade tarzları birbirlerine benzer olduğundan dolayı bu maddelerin hata terimleri arasında modifikasyonlar yapılmıştır. 
Tablo 1: Doğrulayıcı Faktör Analizi ve Güvenilirlik Sonuçları

\begin{tabular}{|c|c|c|c|c|c|c|c|c|}
\hline \multicolumn{2}{|l|}{ Faktör } & $\begin{array}{c}\text { Standardize } \\
\text { edilmiş } \\
\text { yükler }\end{array}$ & t-değeri & $\begin{array}{c}\text { Alfa } \\
\text { Katsayısı }\end{array}$ & $\begin{array}{c}\text { Birleşik } \\
\text { Güvenilirlik } \\
\text { (CR) }\end{array}$ & $\begin{array}{c}\text { Açıklanan } \\
\text { varyans } \\
\text { (AVE) }\end{array}$ & Ort. & $\begin{array}{c}\text { Std. } \\
\text { sapma }\end{array}$ \\
\hline \multicolumn{2}{|c|}{ Marka Deneyimi } & & & 0,892 & 0,93 & 0,54 & & \\
\hline \multirow{3}{*}{ Duyusal Deneyim } & Duyu1 & 0,85 & * & & & & 5,63 & 1,666 \\
\hline & Duyu2 & 0,85 & 12,50 & & & & 5,46 & 1,721 \\
\hline & Duyu 3 & 0,35 & 4,49 & & & & 5,62 & 1,892 \\
\hline \multirow{3}{*}{ Duygusal Deneyim } & Duygu1 & 0,87 & * & & & & 5,63 & 1,649 \\
\hline & Duygu2 & 0,81 & 13,32 & & & & 6,07 & 1,298 \\
\hline & Duygu3 & 0,61 & 8,77 & & & & 4,34 & 1,887 \\
\hline \multirow{3}{*}{ Düşünsel Deneyim } & Düşün1 & 0,88 & * & & & & 5,24 & 1,705 \\
\hline & Düşün2 & 0,83 & 13,72 & & & & 5,38 & 1,694 \\
\hline & Düşün3 & 0,59 & 8,43 & & & & 5,64 & 1,652 \\
\hline \multirow{3}{*}{ Davranışsal Deneyim } & Davran1 & 0,76 & * & & & & 5,08 & 1,555 \\
\hline & Davran2 & 0,49 & 6,41 & & & & 5,80 & 1,443 \\
\hline & Davran3 & 0,71 & 9,50 & & & & 5,57 & 1,488 \\
\hline \multicolumn{2}{|l|}{ Marka Aşkı } & & & 0,937 & 0,97 & 0,72 & & \\
\hline \multirow{4}{*}{ Marka Benlik Bütünleşimi } & Benlik1 & 0,76 & * & & & & 4,57 & 1,910 \\
\hline & Benlik2 & 0,78 & 14,19 & & & & 4,67 & 1,927 \\
\hline & Benlik3 & 0,88 & 12,22 & & & & 4,54 & 1,848 \\
\hline & Benlik4 & 0,84 & 11,57 & & & & 4,14 & 2,054 \\
\hline \multirow{3}{*}{ Tutku-Odaklı Davranışlar } & Tutku1 & 0,80 & * & & & & 5,31 & 1,847 \\
\hline & Tutku2 & 0,77 & 11,33 & & & & 5,15 & 1,763 \\
\hline & Tutku3 & 0,72 & 10,41 & & & & 4,72 & 1,948 \\
\hline \multirow{3}{*}{ Pozitif Duygusal Bağ } & Duygbag1 & 0,85 & * & & & & 4,50 & 1,866 \\
\hline & Duygbag2 & 0,80 & 13,17 & & & & 4,45 & 1,884 \\
\hline & Duygbag3 & 0,76 & 12,13 & & & & 5,37 & 1,693 \\
\hline Uzun Süreli IIlişki & Uzun 1 & 1,00 & * & & & & 5,61 & 1,581 \\
\hline Sezinlenen Ayrılık Endişesi & Ayrılık1 & 1,00 & * & & & & 4,72 & 2,110 \\
\hline Tutum Değer Düzeyi & Tutum 1 & 1,00 & * & & & & 5,97 & 1,410 \\
\hline \multicolumn{2}{|c|}{ Marka Sadakati } & & & 0,957 & 0,96 & 0,65 & & \\
\hline \multirow{5}{*}{ Bilişsel Sadakat } & Blssad1 & 0,74 & * & & & & 5,44 & 1,737 \\
\hline & Blssad2 & 0,85 & 16,71 & & & & 5,55 & 1,637 \\
\hline & Blssad3 & 0,81 & 10,88 & & & & 5,82 & 1,492 \\
\hline & Blssad4 & 0,54 & 7,05 & & & & 3,98 & 1,890 \\
\hline & Blssad5 & 0,73 & 9,68 & & & & 5,03 & 1,676 \\
\hline \multirow{5}{*}{ Duygusal Sadakat } & Duygsad1 & 0,53 & * & & & & 3,64 & 1,843 \\
\hline & Duygsad2 & 0,86 & 7,64 & & & & 5,43 & 1,700 \\
\hline & Duygsad3 & 0,88 & 7,69 & & & & 5,42 & 1,666 \\
\hline & Duygsad4 & 0,90 & 7,79 & & & & 5,65 & 1,634 \\
\hline & Duygsad5 & 0,84 & 7,55 & & & & 5,20 & 1,745 \\
\hline \multirow{4}{*}{ Çabasal Sadakat } & Cabasad1 & 0,85 & * & & & & 5,20 & 1,737 \\
\hline & Cabasad2 & 0,92 & 17,08 & & & & 5,51 & 1,654 \\
\hline & Cabasad3 & 0,93 & 17,75 & & & & 5,67 & 1,536 \\
\hline & Cabasad4 & 0,78 & 12,74 & & & & 4,90 & 1,854 \\
\hline
\end{tabular}

*Değişken ölçeğe sabitlenmiştir.

Model uyum değerleri: $x^{2}=1196,03 ; p=0,00 ;$ d.f. $=624 ; N N F I=0,87 ; I F I=0,90 ; C F I=0,89 ; R M S E A=0,072$ 
Öncelikle, DFA'daki veri ile faktör yapısının uyumunu gösteren uyum iyiliği testleri incelenmiştir. Model uyum iyiliği değerlerine göre $\left(X^{2}\left(624_{\text {sd }}\right)=\right.$ $1196,03(p=0,00), N N F I=0,87, I F I=0,90, C F I=0,89$, RMSEA $=0,072)$, faktör yapısı ile veri arasındaki uyum kabul edilebilir sınırlar içerisindedir (Hair vd., 2013: 630; Tabachnick ve Fidell, 2013: 739).

DFA sonuçlarına göre, örtük değişkenler ile gözlenen değişkenler arasındaki standardize edilmiş parametre değerleri 0,35 ile 0,93 arasında değişmektedir. Ancak, 0,50'nin altında kalmakta olan iki değer (Duyu3 ve Davran2) istatistiksel olarak anlamlı çıktığından $(p \leq 0,05)$ ve içerik geçerliliği sağlandığından dolayı bu değerler çalışmadan çıkarılmamıştır (Hair vd., 2013: 617). Ayrıca, tüm t değerleri 4,49 ile 17,75 arasında, tüm açıklanan varyans (AVE) değerleri 0,54 ile 0,72 arasında ve tüm birleşik güvenilirlik (CR) değerleri 0,93 ve 0,97 aralığında değişmekte olduğundan yakınsama geçerliliği sağlanmıştır (Anderson ve Gerbing, 1988; Babin vd., 2000; Bagozzi vd., 1991; Chau, 1997; Fornell ve Larcker, 1981; Hair vd., 2013). Bunun yanı sıra, kullanılan ölçeklerin Cronbach Alfa güvenilirlik katsayıları 0,892 ile 0,957 arasında değişmekte olup, sosyal bilimlerde kabul edilebilir sınır olan 0,70 'den yüksektir (Nunnally, 1978).

Ortak yöntem sapması sorununun olup olmadığını test etmek amacı ile Harman'ın tek faktör testi kullanılmıştır (Podsakoff ve Organ, 1986). Bütün değişkenler tek bir faktöre yüklenerek DFA tekrar uygulanmıştır (Podsakoff vd., 2003). Analizin sonucuna göre, veri ile faktör yapısı arasında zayıf bir uyum olduğu gözlenmiştir ( $x^{2}=3633,54 ; p=0,00$; d.f.= 702; NNFI=0,68; IFI=0,70; CFI=0,69; RMSEA =0,154). Buna dayanarak ortak yöntem sapmasının çalışma için bir problem teşkil etmediği söylenebilir.

\subsection{Yapısal Eşitlik Modeli Uygulaması Sonuçları}

Kavramsal çerçevede yer alan üç değişkenli model için aracılık testi yapısal eşitlik modeli ile LISREL programı kullanılarak yapıımıştır (Ek 3). Anket soruları her bir boyutu temsil eden aritmetik ortalamalar hesaplanarak hipotez testine dahil edilmiştir. Çalışmanın hipotezlerini analiz etmek için Baron ve Kenny'nin (1986) yönteminden yararlanılmıştır. Baron ve Kenny'nin (1986) aracılık etkisi için önermiş oldukları koşullar şu şekildedir: (a) Bağımsız değişkene ait değişkenlik seviyeleri farzedilen aracı değişkene ait değişkenlikler ile önemli ölçüde açıklanır; (b) Aracı değişkene ait değişkenlikler, bağımlı değişkene ait değişkenlikler ile önemli ölçüde açıklanır; (c) a ve b koşulları kontrol altına alındığı zaman, bağımsız değişkenin bağımlı değişken üzerindeki etkisinin sıfır olduğu ve bu iki değişken arasında daha önceden var olan anlamlı ilişkinin artık anlamlı olmadığı görülür. Bu durum, en güçlü aracılık etkisinin oluştuğunun göstergesidir.

Öncelikle, model uyum iyiliği değerleri $\left(\chi^{2}\left(62_{\text {sd }}\right)=\right.$ $118,38(p=0,00), N N F I=0,96,|F|=0,97, C F I=0,97$, RMSEA $=0,072$, veri ile model arasındaki uyumun istatistiksel olarak kabul edilebilir sınırlar içerisinde olduğunu göstermektedir (Çokluk vd., 2012: 271-272; Hair vd., 2013: 630; Tabachnick ve Fidell, 2013: 739).

Şekil 2'de yer alan kavramsal model ve Tablo 2'de yer alan değerler incelendiğinde, marka deneyiminin marka aşkı üzerinde pozitif yönlü ve anlamlı bir etkisinin olduğu görülmektedir $\left(H_{1}: \beta=0,91, p<0,05\right)$. Bu nedenle, $\mathrm{H}_{1}$ hipotezi kabul edilmiştir. Aynı şekilde, marka aşkının marka sadakati üzerinde pozitif yönlü ve anlamlı bir etkisinin bulunduğu tespit edilmiştir $\left(H_{2}: \beta=0,84, p<0,05\right)$. Dolayısıyla, $H_{2}$ hipotezi kabul edilmiştir.

Şekil 2: Yapısal Eşitlik Modeli Sonuçlarının Kavramsal Model Üzerinde Gösterilmesi



* Bütün t değerleri $p<0,05$ düzeyinde istatistiksel olarak anlamlı bulunmuştur.

Şekil 3'te yer alan yol diyagramına göre, marka deneyiminin marka sadakati üzerinde pozitif yönlü ve anlamlı bir etkisinin olduğu belirlenmiştir $\left(H_{3}: \beta=0,73\right.$, $p<0,05)$. Bu nedenle, $H_{3}$ hipotezi kabul edilmiştir.

Şekil 3: Yapısal Eşitlik Modeli Sonuçları

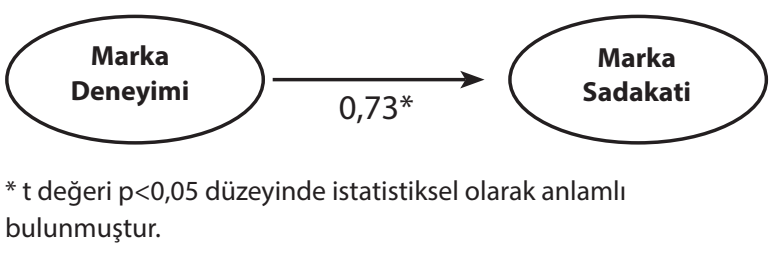


Bunun dışında, çalışmanın dördüncü hipotezini test etme amacıyla, marka aşkı değişkeni modele eklendiğinde (Şekil 2), marka deneyimi ile marka sadakati arasında önceden var olan ilişkinin $\left(\mathrm{H}_{3}\right.$ : $\beta=0,73, \quad p<0,05)$, artık istatistiksel olarak anlamlı olmadığı görülmektedir $\left(H_{4}: \beta=0,00 ; p>0,05\right) . H_{4}$ hipotezinde öngörülenden farklı olarak, marka aşkının marka deneyimi ile marka sadakati arasındaki ilişkiyi dolaylı olarak azaltmak yerine, bu iki yapı arasındaki ilişkiyi istatistiksel olarak anlamsız hale getirdiği ve tam aracılık etkisi gösterdiği görülmektedir. Sonuç olarak, $\mathrm{H}_{4}$ hipotezi reddedilmiştir.

Tablo 2: Hipotez Test Sonuçları

\begin{tabular}{|l|c|c|c|c|}
\hline Hipotezler & $\begin{array}{c}\text { Standardize } \\
\text { Edilmiş } \\
\text { Değerler }\end{array}$ & t-Değeri & p-Değeri & $\begin{array}{c}\text { Hipotez } \\
\text { Durumu }\end{array}$ \\
\hline $\mathbf{H}_{\mathbf{1}}:$ Marka deneyimi $\rightarrow$ Marka aşkı & 0,91 & 11,52 & $<0,05$ & Kabul \\
\hline $\mathbf{H}_{2}:$ Marka aşkı $\rightarrow$ Marka sadakati & 0,84 & 4,57 & $<0,05$ & Kabul \\
\hline $\mathbf{H}_{\mathbf{3}}:$ Marka deneyimi $\rightarrow$ Marka sadakati & 0,73 & 9,62 & $<0,05$ & Kabul \\
\hline $\mathbf{H}_{4}:$ Marka deneyimi $\rightarrow$ Marka aşkı $\rightarrow$ Marka sadakati & 0,00 & 0,01 & $>0,05$ & Red \\
\hline
\end{tabular}

Model uyum değerleri: $\mathrm{X}^{2}=118,38 ; \mathrm{p}=0,00 ;$ d.f. $=62 ; \mathrm{NNFI}=0,96 ; \mathrm{IFI}=0,97 ; \mathrm{CFI}=0,97 ; \mathrm{RMSEA}=0,072$

Baron ve Kenny'nin (1986) koşulları sağlandıktan sonra, marka aşkının marka deneyimi ve marka sadakatiarasındaki ilişkiye aracılık etkisinin istatistiksel olarak anlamlı olup olmadığını test etmek amacı ile Sobel test uygulanmıştır. Sobel test sonuçlarına göre, marka aşkının aracılık etkisinin istatistiksel olarak anlamlı olduğu kanıtlanmıştır (Sobel z-değeri=4,25; $\mathrm{p}=0,00)$.

\section{SONUÇ VE ÖNERILER}

Geleneksel pazarlamayaklaşımınagöre, tüketiciler sadece ürünlerin işlevsel özellikleri ve faydalarına önem veren rasyonel karar verme mekanizmalarıdır. Ancak, gerçekte tüketicilerin karar verirken sadece rasyonel değil aynı zamanda duygusal davranmaları çalışmanın yürütülmesinin temelini oluşturmaktadır. Çalışmanın amacı doğrultusunda marka aşkının marka deneyimi ile marka sadakati arasındaki ilişki üzerinde aracılık etkisi olup olmadığı incelenmiştir.

Çalışmanın sonuçlarına göre, marka deneyiminin marka aşkı üzerinde olumlu bir etki yarattığı bulunmuştur. Marka ile yaşanmış olan deneyimin, tüketicilerin o markaya karşı hissettikleri duyguların güçlenmesine sebep olduğu düşünülmektedir. Deneyimler sonucunda tüketicilerin kendilerini marka ile bir bütün olarak görmeye başladığı söylenebilir. Ayrıca, bu çalışma marka aşkı ile marka sadakati arasındaki pozitif yönlü ilişkiyi istatistiksel olarak desteklemektedir. Marka ile aralarında duygusal bağ kuran tüketicilerin, marka sadakatlerinin diğer tüketicilere kıyasla daha güçlü olması ve oluşan duygusal bağın tüketicilerin satın alma sonrası davranışlarında olumlu etkiler yaratması beklenmektedir. Bunun yanı sıra, çalışmanın sonuçları marka deneyimi ile marka sadakati arasında pozitif yönlü bir ilişki olduğunu göstermektedir. Markalar ve tüketiciler arasındaki ilişki, marka deneyimi yoluyla pekiştirilebilmekte ve daha uzun dönemli hale dönüşebilmektedir. Diğer bir yandan, çalışmanın asıl amacını oluşturan marka aşkının aracılık etkisi doğrulanmıştır. Tüketicilere deneyimler yaşatılarak yaratılan aşk markalarının tüketicilerin marka sadakatleri üzerinde daha güçlü bir etki bırakacağı düşünülmektedir.

Çalışmanın bulgularının yöneticilere önemli katkılar sağlayacağı beklenmektedir. Marka deneyiminin marka sadakatini doğrudan, marka aşkı üzerinden ise dolaylı olarak etkilediğinin farkında olan yöneticiler marka uyarıcılarını kullanarak müşterilerine hoşnut kalacakları bir deneyim yaşatmaları sonucu markalarını birer aşk markası haline dönüştürebilirler. Buna bağlı olarak, tüketicilerin o markaya eskiye oranla daha fazla sadık olmalarını sağlayabilirler. Örneğin, MediaCatIpsos işbirliğinde gerçekleşen ve Türk tüketicilerinin aşk markalarını belirlemeye yönelik olan Türkiye'nin Lovemark'ları 2014 Araştırması'nın sonuçlarına göre, süpermarket kategorisinin aşk markası Migros seçilmiştir (MediaCat Online, 2014). Bu başarıyı Migros'un tüketicilerine sunduğu benzersiz alışveriş deneyimlerine dayandırmak mümkündür.

Buna ek olarak, çalışma sonuçlarından otomobil firmalarına yönelik önemli çıkarımlar yapılabilir. 
Aşk markası yaratmak ve tüketicilere farklı deneyimler yaşatmak için, otomobil firma yöneticileri marka deneyimi alt bileşenlerini göz önüne alarak stratejiler geliştirebilirler. Örneğin, tüketicilerin beş duyu organına hitap eden duyusal deneyimler otomobillere uygulanan farklı ve özgün tasarımlar ile yaratılabilir. Buna ek olarak, konumlandırma yoluyla oluşturulan marka kişiliğinin ve imajının (örn., Volvo sağlamlık, güvenlik) tüketicilere duygusal deneyimler yaşatmada etkili olabileceği düşünülmektedir. Bundan başka, otomobil firmaları marka toplulukları yaratarak tüketicilerine ilişki deneyimleri yaşatabilirler. Sonuç olarak, otomobil firmaları yöneticilerinin marka deneyimleri sunmak ve marka aşkını güçlendirmeye yönelik stratejiler geliştirmelerinin aşk markası yaratmada etkili olacağı ve marka sadakatini uzun vadede olumlu yönde etkileyeceği beklenmektedir.

Araştırmanın zaman, erişim ve finansal sebeplerden dolayı birtakım sınırlılıkları da bulunmaktadır. Verileri toplarken kolayda örnekleme yönteminin kullanılması katılımcılara hızlı ulaşımasını sağlaması ve düşük maliyetli olması açısından fayda sağlıyor olsa da, bu yöntem çalışma için örnekleme yöntemi sınırlılığı oluşturmaktadır. Ayrıca, çalışmanın sadece otomotiv sektöründe uygulanması, çalışmanın sonuçlarının diğer sektörlere genellenebilirliği açısından bağlam sınırlıı̆̆ı yaratmaktadır.

Gelecekte gerçekleştirilecek olan çalışmalarda marka deneyimi ve marka sadakati alt bileşenlerinin kendi aralarındaki etkileşimlerinin ayrı ayrı incelenmesi önerilmektedir. Buna ek olarak, marka kişiliği ve benlik imajı uyumu gibi değişkenlerin marka aşkının öncülleri, marka denkliği ve ağızdan ağıza pazarlama gibi değişkenlerin marka aşkının sonuçları olarak test edilmesinin literatüre önemli katkılar sağlayacağı düşünülmektedir.

Çalışma marka aşkının marka deneyimi ile marka sadakati arasındaki ilişki üzerindeki aracılık etkisine ışık tutmaktadır. Çalışmada önerilmiş ve geçerliliği sağlanmış olan kavramsal çerçevenin gelecekteki çalışmalara yön vermesi beklenmektedir.

\section{SON NOTLAR}

'Bu çalışmanın ilk şekli 19. Ulusal Pazarlama Kongresi, Haziran 2014 Gaziantep'te sunulmuş olup, özet hali Bildiri Kitabı'nda yayınlanmıştır.

\section{KAYNAKLAR}

Albert, N., Merunka, D. ve Valette-Florence, P. (2008) "When Consumers Love Their Brands: Exploring the Concept and its Dimensions" Journal of Business Research, 61(10): 1062-1075.

Albert, N. ve Merunka, D. (2013) "The Role of Brand Love in Consumer-Brand Relationship" Journal of Consumer Marketing, 30(3): 258-266.

Almeida, S. ve Nique, W. (2005) "Consumer Delight: An Attempt to Comprehend the Dimensions That Compose the Construct and its Behavioral Consequences" AMA Winter Educators Konferansı, Şubat 11-14, San Antonio, Texas, USA.

Anderson, J. ve Gerbing, D. (1988) "Structural Equation Modelling in Practice: A Review and Recommended Two-Step Approach" Psychological Bulletin, 103(3): 411-423.

Babin, B., Boles, J. ve Robin, D. (2000) "Representing the Perceived Ethical Work Climate among Marketing Employees" Journal of the Academy of Marketing Science, 28(3): 345-358.

Back, K. ve Parks, S. C. (2003) "A Brand Loyalty Model Involving Cognitive, Affective, and Conative Brand Loyalty and Customer Satisfaction" Journal of Hospitality and Tourism Research, 27(4): 419435.

Bagozzi, R.,Yi,Y. ve Philips,L. (1991) "Assessing Construct Validity in Organisational Research" Administrative Science Quarterly, 36(3): 421-458.

Bagozzi, R., Batra, R. ve Ahuvia, A. (2014) "Brand Love: Construct Validity, Managerial Utility, and New Conceptual Insights" Ön makale, Ann Arbor, MI: University of Michigan.

Baron, R. ve Kenny, D. (1986) "The Moderator-Mediator Variable Distinction in Social Psychological Research: Conceptual, Strategic, and Statistical Considerations" Journal of Personality and Social Psychology, 51(6): 1173-1182.

Batra, R., Ahuvia, A. ve Bagozzi, R. (2012) "Brand Love" Journal of Marketing, 76(2): 1-16.

Bauer, H., Heinrich, D. ve Albrecht, C. (2009) "All You Need is Love: Assessing Consumers'Brand Love" American Marketing Association Summer Educators Konferansı, Ağustos 7-10, Chicago, USA.

Bergkvist, L. ve Bech-Larsen, T. (2010) "Two Studies of Consequences and Actionable Antecedents of Brand Love" Journal of Brand Management, 17(7): 504-518.

Brakus, J. J., Schmitt, B. H. ve Zarantonello, L. (2009) "Brand Experience: What is it? How is it Measured? Does it Affect Loyalty?" Journal of Marketing, 73(3): 52-68.

Carroll, B. ve Ahuvia, A. (2006) "Some Antecedents and Outcomes of Brand Love" Marketing Letters, 17(2): 79-90. Chang, P. L. ve Chieng, M. H. (2006) "Building Consumer-Brand Relationship: A Cross Cultural Experiential View" Journal of Psychology and Marketing, 23(11): 927-959.

Chau, P. (1997) "Re-Examining a Model for Evaluating Information Centre Success Using a Structural Equation Modelling Approach" Decision Science, 28(2): 309-334. 
Cooper-Martin, E. (1993) "Effects of Information Format and Similarity Among Alternatives on Consumer Choice Processes" Journal of the Academy of Marketing Sciences, 21(3): 239-246.

Çokluk, Ö., Şekercioğlu, G. ve Büyüköztürk, Ş. (2012) Sosyal Bilimler için Çok Değişkenli Istatistik SPSS ve LISREL Uygulamaları, Ankara, Türkiye, Pegem Akademi.

Dick, A. S. ve Basu, K. (1994) "Customer Loyalty: Toward an Integrated Conceptual Framework" Journal of the Academy of Marketing Science, 22(2): 99-113.

Ding, C. G. ve Tseng, T. H. (2015) "On the Relationships among Brand Experience, Hedonic Emotions, and Brand Equity" European Journal of Marketing, 49(7/8): 994-1015.

Fornell, C. ve Larcker, D. F. (1981) "Evaluating Structural Equation Models with Unobservable Variables and Measurement Error" Journal of Marketing Research, 18(1): 39-50.

Fournier, S. (1998) "Consumers and Their Brands: Developing Relationship Theory in Consumer Research" Journal of Consumer Research, 24(4): 343-372.

Francisco-Maffezzolli, E. C., Semprebon, E ve Prado, P. H. M. (2014) "Construing Loyalty through Brand Experience: The Mediating Role of Brand Relationship Quality" Journal of Brand Management, 21(5): 446-458.

Hair, J., Black, W., Babin, B. ve Anderson, R. (2013) Multivariate Data Analysis: Pearson New International Edition, USA, Pearson Education Limited.

Holbrook, M. B. ve Hirschman, E. C. (1982) "Experiential Aspects of Consumption: Consumer Fantasies, Feelings, and Fun" Journal of Consumer Research, 9(2): 132-140.

Iglesias, O., Singh, J. J. ve Batista-Foguet, J. M. (2011) "The Role of Brand Experience and Affective Commitment in Determining Brand Loyalty" Journal of Brand Management, 18(8): 570-582.

Jacoby, J. ve Kyner, D. B. (1973) "Brand Loyalty vs. Repeat Purchasing Behavior" Journal of Marketing Research, 10(1): 1-9.

Kumar, A. (1996) "Consumer Delight: Creating and Maintaining Competitive Advantage" Yayınlanmamış Doktora Tezi, Bloomington, USA, Indiana University.

Langner, T., Bruns, D., Fischer, A. ve Rossiter, J. R. (2014) "Falling in Love With Brands: A Dynamic Analysis of the Trajectories of Brand Love" Marketing Letters, 1-12.

Mano, H. ve Oliver, R. (1993) "Assessing the Dimensionality and Structure of Consumption Experience" Journal of Consumer Research, 20(3): 451-466.

MediaCat Online (2014), http://www.mediacatonline.com/brandweek-istanbul-lovemarks-2014-odulleri/, (06.10.2015).

Nadiri, H. ve Günay, G. N. (2013) "An Empirical Study to Diagnose the Outcomes of Customers' Experiences in Trendy Coffee Shops" Journal of Business Economics and Management, 14(1): 22-53.

Nunnally, J. C. (1978) Psychometric Theory, New York, USA, McGrawHill.

Nysveen, H., Pedersen, P. E. ve Skard, S. (2013) "Brand Experiences in Service Organizations: Exploring the Individual Effects of Brand Experience Dimensions" Journal of Brand Management, 20(5): 404423.

Nysveen, H. ve Pedersen, P. E. (2014) "Influences of Co-creation on Brand Experience: The Role of Brand Engagement" International Journal of Market Research, 56(6): 807-832.
Oliver, R. L. (1999) "Whence Consumer Loyalty?" Journal of Marketing, 63: 33-44.

Pawle, J., ve Cooper, P. (2006) "Measuring Emotion - Lovemarks, the Future Beyond Brands" Journal of Advertising Research, 46(1): 38-48.

Pine, B. J. ve Gilmore, J. H. (1998) "Welcome to the Experience Economy" Harvard Business Review, 97-105.

Podsakoff, P. M. ve Organ, D. W. (1986) "Self-Reports in Organizational Research: Problems and Prospects" Journal of Management, 12(4): 531-544.

Podsakoff, P. M., MacKenzie, S. B., Lee, J. Y. ve Podsakoff, N. P. (2003) "Common Method Biases in Behavioral Research: A Critical Review of the Literature and Recommended Remedies" Journal of Applied Psychology, 88(5): 879-903.

Ramaseshan, B. ve Stein, A. (2014) "Connecting the Dots between Brand Experience and Brand Loyalty: The Mediating Role of Brand Personality and Brand Relationships" Journal of Brand Management, 24: 664-683.

Roberts, K. (2004) Lovemarks: The future beyond brands, New York, USA, Power House Books.

Roy, S., Eshghi, A. ve Sarkar, A. (2013) "Antecedents and Consequences of Brand Love" Journal of Brand Management, 20(4): 325-332.

Schmitt, B. H. (1999) "Experiential Marketing" Journal of Marketing Management, 15(1-3): 53-67.

Schmitt, B. H. ve Zarantonello, L. (2013) "Consumer Experience and Experiential Marketing: A Critical Review" Review of Marketing Research, 10: 25-61.

Shimp, T. ve Madden, T. (1988) "Consumer-Object Relations: A Conceptual Framework Based Analogously on Sternberg's Triangular Theory of Love" Advances in Consumer Research, 15(1): 163-168.

Sternberg, R. (1986) "A Triangular Theory of Love" Psychology Review, 93(2): 1-28.

Tabachnick, B. G. ve Fidell, L. S. (2013) Using Multivariate Statistics, USA, Pearson Education.

Thomson, M., Maclnnis, D. ve Park, C. (2005) "The Ties That Bind: Measuring the Strength of Consumers' Emotional Attachments to Brands" Journal of Consumer Psychology, 15(1): 77-91.

Ünal, S. ve Aydın, H. (2013) "An Investigation on the Evaluation of the Factors Affecting Brand Love" Procedia-Social and Behavioral Sciences, 92: 76-85.

Walter, N., Cleff, T. ve Chu, G. (2013) “Brand Experience's Influence on Customer Satisfaction and Loyalty: A Mirage in Marketing Research" International Journal of Management Research and Business Strategy, 2(1): 130-144.

Zarantonello, L. ve Schmitt, B. H. (2010) “Using the Brand Experience Scale to Profile Consumers and Predict Customer Behavior" Journal of Brand Management, 17(7): 532-540. 


\section{EK 1}

Değerli Katılımcı,

Elinizdeki soru formu yürütülmekte olan akademik bir çalışma için hazırlanmıştır. Elde edilen veriler yalnızca bilimsel amaçı kullanılacak olup, istenildiği takdirde sonuçlar paylaşılacaktır. Soru formunun doldurulması yaklaşık olarak 5 dakikanızı alacaktır. Vereceğiniz yanıtların bizim için önemli olduğunu belirtir, ayırdığınız zaman için çok teşekkür ederiz.

\section{BÖLÜM}

Eğer otomotiv sektöründen bir ürünü alabilmeniz için size bir seçim hakkı sunulmuş olsaydı, markalarla yaşadığınız deneyimleri göz önüne alarak (markanın da içerisinde bulunduğu anılarınız), almayı en çok isteyeceğiniz markayı lütfen aşağıdaki boşluğa belirtiniz.*

(Marka deneyimi:Tüketicinin geçmişte markayı kullanmasıveya markaile etkileşim kurması-ürünle karşılaşması, televizyon reklamı, broşür, gazete reklamı, web sayfası gibi herhangi bir iletişim aracında görmesi- sonucu edindiği tecrübeler bütünü olarak tanımlanmaktadır.)

*Lütfen bundan sonraki soruları aşağıda belirtmiş olduğunuz markayı düşünerek yanıtlayınız.

\section{BÖLÜM}

Yanıtlarda (1) “Hiç katılmıyorum”, (7) “Tamamen katılıyorum” ifadelerine karşılık gelmektedir. Lütfen sizin için en uygun olan seçeneği ilgili rakamı yuvarlak içine alarak belirtiniz.

\begin{tabular}{|c|c|c|c|c|c|c|c|c|}
\hline & Marka Deneyimi & $\begin{aligned} \text { Hiç } \\
\text { katımiyor }\end{aligned}$ & & & & & & $\begin{array}{l}\text { Tamamen } \\
\text { katillyorum }\end{array}$ \\
\hline Duyu1 & $\begin{array}{l}\text { Bu marka beş duyumun herhangi birinin (görme, işitme, } \\
\text { tatma, dokunma ve koklama) üzerinde güçlü bir etki } \\
\text { yaratır. }\end{array}$ & 1 & 2 & 3 & 4 & 5 & 6 & 7 \\
\hline Duyu2 & Bu markayı beş duyum açısından ilgi çekici buluyorum. & 1 & 2 & 3 & 4 & 5 & 6 & 7 \\
\hline Duyu 3 & Bu marka beş duyumdan herhangi birisine hitap etmiyor. & 1 & 2 & 3 & 4 & 5 & 6 & 7 \\
\hline Duygu 1 & Bu marka duygularımı harekete geçirir. & 1 & 2 & 3 & 4 & 5 & 6 & 7 \\
\hline Duygu2 & Bu marka için olumlu duygular beslerim. & 1 & 2 & 3 & 4 & 5 & 6 & 7 \\
\hline Duygu3 & Bu marka duygusal bir markadır. & 1 & 2 & 3 & 4 & 5 & 6 & 7 \\
\hline Davran1 & $\begin{array}{l}\text { Bu marka kişiyi fiziksel olarak harekete geçiren bir } \\
\text { markadır. }\end{array}$ & 1 & 2 & 3 & 4 & 5 & 6 & 7 \\
\hline Davran2 & $\begin{array}{l}\text { Bu markayı kullanmak, bedensel bir deneyim yaşamamı } \\
\text { sağlar. }\end{array}$ & 1 & 2 & 3 & 4 & 5 & 6 & 7 \\
\hline Davran3 & Bu marka kişiyi harekete geçiren bir nitelik taşımaz. & 1 & 2 & 3 & 4 & 5 & 6 & 7 \\
\hline Düşün1 & Bu markayı görünce birçok fikir aklıma gelir. & 1 & 2 & 3 & 4 & 5 & 6 & 7 \\
\hline Düşün2 & Bu marka bana çok şey çağrıştırmaz. & 1 & 2 & 3 & 4 & 5 & 6 & 7 \\
\hline Düşün3 & Bu marka bende merak isteği uyandırır. & 1 & 2 & 3 & 4 & 5 & 6 & 7 \\
\hline
\end{tabular}




\section{BÖLÜM}

\begin{tabular}{|c|c|c|c|c|c|c|c|c|}
\hline & Marka Aşkı & $\begin{array}{c}\text { Hic } \\
\text { katilmiyorur }\end{array}$ & & & & & & $\begin{array}{l}\text { Tamamen } \\
\text { katillyorum }\end{array}$ \\
\hline Benlik1 & Bu marka kim olduğumu en iyi şekilde anlatır. & 1 & 2 & 3 & 4 & 5 & 6 & 7 \\
\hline Benlik2 & $\begin{array}{l}\text { Bu marka benim görünmek istediğim biri gibi } \\
\text { görünmemi sağlar. }\end{array}$ & 1 & 2 & 3 & 4 & 5 & 6 & 7 \\
\hline Benlik3 & Bu marka hayatımı oldukça anlamlandırır. & 1 & 2 & 3 & 4 & 5 & 6 & 7 \\
\hline Benlik4 & Bu markayı çok sık düşünürüm. & 1 & 2 & 3 & 4 & 5 & 6 & 7 \\
\hline Tutku1 & Her zaman bu markayı kullanmak isterim. & 1 & 2 & 3 & 4 & 5 & 6 & 7 \\
\hline Tutku2 & Geçmişten beri bu marka ile yakından ilgilenirim. & 1 & 2 & 3 & 4 & 5 & 6 & 7 \\
\hline Tutku3 & $\begin{array}{l}\text { Bu ürünü kendime daha uyumlu hale getirmek ve/ } \\
\text { veya geliştirmek için para, zaman ve emek harcamaya } \\
\text { gönüllü olurum }\end{array}$ & 1 & 2 & 3 & 4 & 5 & 6 & 7 \\
\hline Duygbag1 & Bu marka ile aramda doğal bir uyum vardır. & 1 & 2 & 3 & 4 & 5 & 6 & 7 \\
\hline Duygbag2 & Bu markaya duygusal olarak bağlıyım. & 1 & 2 & 3 & 4 & 5 & 6 & 7 \\
\hline Duygbag3 & Bu markanın eğlenceli olduğunu düşünüyorum. & 1 & 2 & 3 & 4 & 5 & 6 & 7 \\
\hline Uzun1 & $\begin{array}{l}\text { Bu markayı uzun bir süre daha kullanmaya devam } \\
\text { edeceğime inanıyorum. }\end{array}$ & 1 & 2 & 3 & 4 & 5 & 6 & 7 \\
\hline Ayrılık1 & $\begin{array}{l}\text { Bu markanın piyasadan kalkacağı fikri beni oldukça } \\
\text { kaygılandırır. }\end{array}$ & 1 & 2 & 3 & 4 & 5 & 6 & 7 \\
\hline Tutum1 & Bu markaya karşı duygularım olumludur. & 1 & 2 & 3 & 4 & 5 & 6 & 7 \\
\hline
\end{tabular}




\section{BÖLÜM}

\begin{tabular}{|c|c|c|c|c|c|c|c|c|}
\hline & Marka Sadakati & $\begin{array}{r}\text { Hiç } \\
\text { katımiyo }\end{array}$ & & & & & & $\begin{array}{c}\text { Tamamen } \\
\text { katillyorum }\end{array}$ \\
\hline Blssad1 & $\begin{array}{l}\text { Bir otomobil satın alırken daima "X" markasını diğer } \\
\text { markalardan çok düşünürüm. }\end{array}$ & 1 & 2 & 3 & 4 & 5 & 6 & 7 \\
\hline Blssad2 & $\begin{array}{l}\text { “X” markasına diğer markaların üzerinde bir dikkat } \\
\text { gösteririm. }\end{array}$ & 1 & 2 & 3 & 4 & 5 & 6 & 7 \\
\hline Blssad3 & $\begin{array}{l}\text { Diğer markalar ile karşılaştırdığımda "X" markası bana } \\
\text { yüksek düzeyde ürün kalitesi sağlar. }\end{array}$ & 1 & 2 & 3 & 4 & 5 & 6 & 7 \\
\hline Blssad4 & $\begin{array}{l}\text { Hiçbir otomobil markası "X" markasından daha iyi bir } \\
\text { ürün sunmaz. }\end{array}$ & 1 & 2 & 3 & 4 & 5 & 6 & 7 \\
\hline Blssad5 & $\begin{array}{l}\text { “X” markasının diğer otomobil markalarından daha fazla } \\
\text { fayda sunduğuna inanıyorum. }\end{array}$ & 1 & 2 & 3 & 4 & 5 & 6 & 7 \\
\hline Duygsad1 & $\begin{array}{l}\text { Eğer "X" markasından başka bir marka almak zorunda } \\
\text { kalırsam kendimi mutsuz hissederim. }\end{array}$ & 1 & 2 & 3 & 4 & 5 & 6 & 7 \\
\hline Duygsad2 & $\begin{array}{l}\text { "X" markasını kullandığım zaman kendimi daha iyi } \\
\text { hissediyorum. }\end{array}$ & 1 & 2 & 3 & 4 & 5 & 6 & 7 \\
\hline Duygsad3 & $\begin{array}{l}\text { “X” markası beni diğer markalardan daha fazla } \\
\text { heyecanlandırıyor. }\end{array}$ & 1 & 2 & 3 & 4 & 5 & 6 & 7 \\
\hline Duygsad4 & $\begin{array}{l}\text { "X" markasını diğer markalardan daha fazla } \\
\text { seviyorum. }\end{array}$ & 1 & 2 & 3 & 4 & 5 & 6 & 7 \\
\hline Duygsad5 & $\begin{array}{l}\text { Kendimi “X” markasına diğer markalardan daha fazla } \\
\text { bağlı hissediyorum. }\end{array}$ & 1 & 2 & 3 & 4 & 5 & 6 & 7 \\
\hline Cabasad1 & $\begin{array}{l}\text { "X" markasını satın almak için benim için diğer bir başka } \\
\text { otomobil markasını satın almaktan daha önemlidir. }\end{array}$ & 1 & 2 & 3 & 4 & 5 & 6 & 7 \\
\hline Cabasad2 & “X” markasını ilk satın alma tercihim olarak görüyorum. & 1 & 2 & 3 & 4 & 5 & 6 & 7 \\
\hline Cabasad3 & “X” markasını kullanmaya devam etmeyi istiyorum. & 1 & 2 & 3 & 4 & 5 & 6 & 7 \\
\hline Cabasad4 & $\begin{array}{l}\text { Diğer markalar ürünlerini daha ucuz fiyatla satsalar bile } \\
\text { hala "X" markasını satın alırım. }\end{array}$ & 1 & 2 & 3 & 4 & 5 & 6 & 7 \\
\hline
\end{tabular}




\section{BÖLÜM}

Lütfen ilgili boşluğu doldurunuz veya uygun kutucuğu işaretleyiniz.

\section{S.1. Cinsiyetiniz: $\square$ Kadın $\square$ Erkek}

S.2. Yaşınız:

S.3. Eğitim durumunuz: $\square$ lilköğretim $\square$ Lise $\square$ Önlisans $\square$ Lisans $\square$ Yükseklisans/Doktora

S.4. Mesleğiniz:

S.5. Aylık ortalama hanehalkı geliriniz:

1000 TL ve altı

$1001-2000 \mathrm{TL}$

2001-3000 TL

$3001-4000 \mathrm{TL}$

$4001-5000 \mathrm{TL}$

$5001-6000 \mathrm{TL}$

$6001-7000 \mathrm{TL}$

$7001-8000 \mathrm{TL}$

8001-9000 TL

9000 TL ve üzeri 


\section{EK 2}

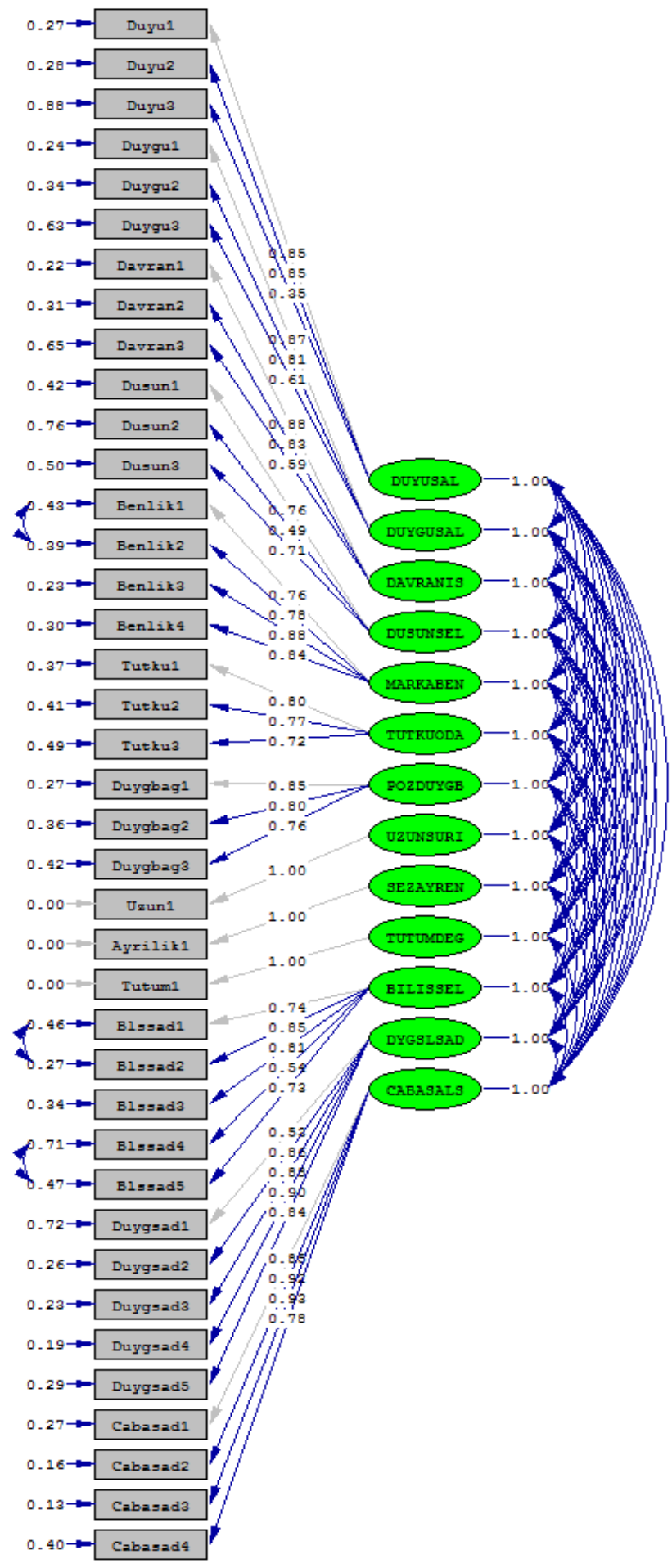

Chi-Square $=1196.03, d f=624, P-$ value $=0.00000, \operatorname{RMSEA}=0.072$

DFA - LISREL PROGRAM ÇIKTISI 


\section{EK 3}

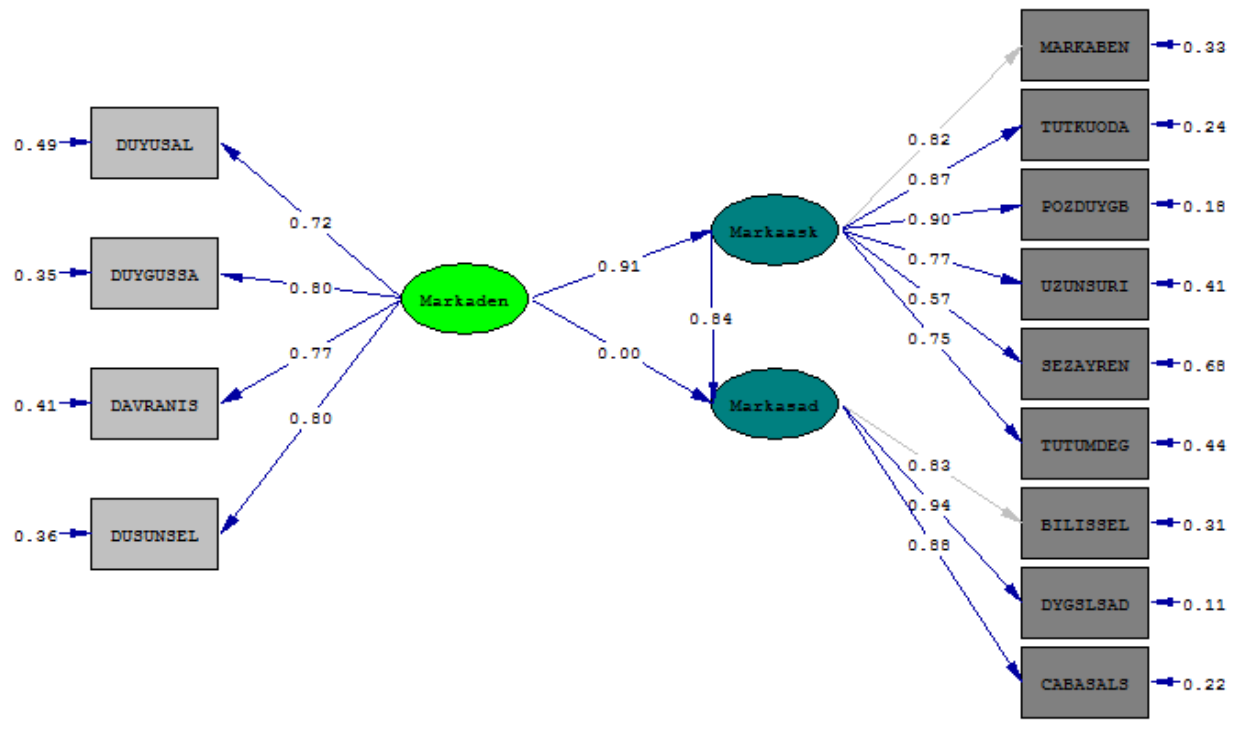

Chi-Square $=118.38, \mathrm{df}=62, \mathrm{P}-\mathrm{value}=0.00002, \mathrm{RMSEA}=0.072$

YEM - LISREL PROGRAM ÇIKTISI 